\title{
Covid-19 Causes Religious Recession on Kbg Matersalvatores in Katedral Ruteng Parish
}

\author{
Raimundus Beda ${ }^{1}$, Agnetis A. Basir ${ }^{2}$, Theodisius F. Rondas ${ }^{3}$ \\ \{raimundusbeda1968@gmail.com ${ }^{1}$, agnetisbasir09@gmail.com², \\ erikrondas08@gmail.com ${ }^{3}$ \}
}

English Language Education Study Program, Universitas Katolik Indonesia Santu Paulus Ruteng, Indonesia ${ }^{1,2,3}$

\begin{abstract}
Covid-19 is a worldwide and very deadly disease, this disease attacks various aspects of human life, especially in religious life. The most visible impact is the decline in the structure of church life, such as the changes of conventional mass to online mass, the restriction of major Christian celebrations, such as cancellation of Christmas and Easter celebration, reduced church income, and spending a lot of money on online mass, reduced community participation due to insufficient facilities to attend online celebrations. This study aims to determine the causes of religious decline during the Covid-19 pandemic as well as to find out the church's solutions, people's views, and solutions in facing the challenges of church life during the Covid-19 pandemic. This study uses quantitative methods to make it easier for writers to collect data. The results of this study indicate that the decline of religion is experienced by the Church and society in the context of not carrying out conventional mass celebrations but switching to an online mass celebration. The solution offered by the Church is that the Church invites all people to obey government regulations by following health protocols and the most important thing is "Pray" to be free from Covid-19, even though no definite solution has yet been found in facing the challenges of Covid-19 in church life. Other findings show that people are still willing to take part in online mass celebrations in all possible ways, including by following celebrations from home, joining celebrations with neighbors, listening to the radio, watching celebrations through television programs, and carrying out personal prayers if they do not have facilities supporters to attend online mass celebrations.
\end{abstract}

Keywords: covid-19; Religious; Religious recession; Church.

\section{INTRODUCTION}

At this time the world was shocked by the Covid-19 pandemic which was deadly and had a bad impact on all mankind, without exception. This has resulted in 
the world being "upside-down" in which many of our "normal" social behaviors have undergone dramatic changes. COVID-19 is a disease caused by a new type of coronavirus, 'CO' stands for corona, 'VI' for the virus, and 'D' for disease. Previously, this disease was referred to as '2019 novel coronavirus' or '2019-nCoV'. This new virus is related to the same virus family as Severe Acute Respiratory Syndrome (SARS) and several types of the common cold (Unicef, 2020). First identified in Wuhan, China, in December 2019 which then spread to most parts of the world, until 3 May 2020, there were around 3,546,758 global cases of COVID-19, 1.137.349 people had recovered from the disease, while there were 247,312 deaths due to the virus (Worldometer, 2020).

Virus prevention efforts are underway worldwide, with lockdowns almost global, social distancing appears and has an effect in reducing the prevalence of infection. One aspect of the lockdown is that places of worship have been temporarily closed and the internet has become the main locus of religious activity. According to the Gallup cited by Frank Newport (2020), stated that " The most dramatic result (in religion) is the very rapid shift away from religious services, from face-to-face to online worship ", while for nearly a hundred years, the church has used a variety of communication methods to reach listeners, such as radio, television and online media. In addition, Gallup (2020) stated that " the outright cessation of worship was one of the most significant abrupt disruptions in religious practice in US history ". It can be concluded that this significant displacement gave rise to real anxiety and unpreparedness of the entire Christian community which would, in turn, create societal passivity and a very rapid decline in religion.

The Covid-19 pandemic has caused the social element of church participation to decline significantly. The factors of age and community income are in the spotlight. Social distance can quickly translate into a rapid reduction in the social benefits of church involvement. If this pandemic lasts longer, then some very critical social capital may be lost which could affect churches in the long term once they try to regroup once the social distancing of the pandemic eases. According to Brian Hollar (2020) stated that "In recent years, regular church attendance as a percentage of the population has continued to decline in the United States ( with decreases being more pronounced in many European countries ) and the percentage of the population claiming to have no religion has continued to increase. This decline in societal religiosity means that fewer people today than in the past are likely to turn to religious institutions for consolation during this pandemic.

Churches that have fewer opportunities for spontaneous direct social interaction could weaken social ties within the church the longer the pandemic lasts. The more successful churches offer a way for people to continue to interact in realtime with one another during a pandemic, the less social capital they hope to lose. The less successful churches provide a genuine sense of community, connectedness, 
and support during this crisis, the more they will find themselves competing with other streaming media for the attention of believers. This "crowding out" effect can reduce the need for individuals to rely on church services to help them get through times of crisis and be more dependent on government and drugs than in the past.

Departing from the topic being discussed, the writer also proposes topics related to religious decline, by focusing more on church solutions in dealing with community passivity and community response in facing online worship / virtual mass. The research was conducted in the area of the Cathedral Ruteng, precisely in the village of Kampung Maumere, East Nusa Tenggara, the eastern part of Indonesia. To limit the data, the writer only focuses on one group, namely the Matersalvatores group. Considering the lack of empirical research on this topic, and there is little information related to the topic, the evidence base for this paper comes mostly from articles and newspapers on the internet showing what is happening to religious beliefs and practices. There is a lot of information on the Internet related to Christianity, which is the main, though not exclusive, focus of this paper. With that, the writer formulated the title " COVID 19 CAUSES RELIGIOUS RECESSION TO KBG MATERSALFATORES IN CATEDRAL RUTENG ”

\section{A. Corona Virus Disease}

Coronavirus disease (COVID-19) is an infectious disease caused by a newly discovered coronavirus. (WHO: 2020). According to UNICEF, WHO, and CIFRC, COVID-19 is a disease caused by a new type of corona virus. 'CO stands for corona,' VI 'for a virus, and' D 'for disease. Previously, the disease was referred to as '2019 novel coronavirus' or '2019-nCoV.' The COVID-19 virus is a new virus that is related to the same virus family as Severe Acute Respiratory Syndrome (SARS) and several types of the common cold.

The virus is transmitted by direct contact with respiratory droplets from an infected person (generated by coughing and sneezing). Individuals can also become infected from surfaces contaminated with the virus and touching their faces (for example, eyes, nose, mouth). There are some symptoms caused by the viruses, such as fever, cough, and shortness of breath. In more severe cases, the infection can cause pneumonia or difficulty breathing. These symptoms are similar to those of the flu (influenza) or the common cold, which are much more common than COVID-19.

According to UNICEF, WHO, CIFRC (2020) stated that people who are aged over 60 years, and people who have underlying medical conditions such as diabetes, heart disease, respiratory disease, or hypertension are among those who are at greater risk of developing severe or critical illness if infected with the virus.

In Indonesia, the 2018 Riskesdas basic health survey data shows that cardiovascular disease and diabetes are among the highest disease burdens in 
the country. Nearly $11 \%$ of Indonesian adults have high blood sugar levels and $1.5 \%$ suffer from heart disease - making this group susceptible to severe COVID-19 symptoms if exposed to the disease. In addition, the same Riskesdas data shows that almost $63 \%$ of adult men in Indonesia smoke. This figure is among the highest smoking prevalence in the world. "Smokers are at high risk for heart and respiratory disease, which are a high-risk factor for developing severe or critical illness with COVID-19," said Dr. Paranie, WHO Representative for Indonesia. "Therefore, smokers in Indonesia are at high risk of contracting COVID-19."

\section{B. Religious Recession}

Defining religion and clarifying its characteristics has been a process that has engulfed researchers since the needs and demands of the scientific study of religious phenomena were formulated. From the beginning, the scholars who laid the foundations for academic studies of religion aimed to define religion. Although it is difficult to define religion, it is necessary to continue with an explanation of the object we are studying. It is a concept known to everyone but at the same time difficult to fit into the same frame of reference. Religion is an analytic-conceptual category that in many cases has been conceptualized and constructed by scholars themselves. There are various definitions of religion developed during the academic study of religion:

a. Belief In A Higher Being (Intellectual Definition),

b. Its Intrinsic Characteristics (I.E., Essentialist Definition), That Is, Certain Properties, Which Are Considered 'Separate' From Other Human Activities And Can Be Considered As Religious,

c. Examination Of Social Functions,

d. Cultural Direction Through Clarifying The Meaning Hidden In The Symbols Of Each Culture.

According to Geertz: Religion is a system of symbols related to the world, human relations, and ourselves. Religious symbols indicate cosmological perceptions, but also shape a way of life. Geertz: Religion is a system of symbols related to the world, human relations, and ourselves. Religious symbols indicate cosmological perceptions, but also shape a way of life.

The term " religion " can be defined as a system of beliefs and practices that relate to supernatural beings and are intended to organize and define the environment in which the religious community operates. Religion has largely become a taxonomic term and comparative category to denote the difference between "we" and "others." Limits are set and it is clear that 'we are the ones who are elected. 
Meanwhile, a recession means that a decline of something. This term is always used economically. Economically, recession means the decline of economic activity in a particular region. Based on reporting from Investopedia (25/11/2019), the National Economic Research Bureau (NBER) defines a recession as "a period of decline in economic activity, spreading throughout the economy and lasting for more than a few months". That means there are fewer jobs, people earning less and spending less and businesses stop growing and maybe even close. The explanation above explained the general terms of recession. So that, what is the writer means about 'religious recession'?

Religious recession means the decline of religion in many ways. The way that religion change is lost. It means that religion turns to be nothing, especially in the pandemic period. In normal times, church attendance is used by sociologists and economists as a representation of religiosity for Christianity. But how do we measure religiosity when people are selfisolating, should churches use their YouTube or Twitch video shows during mass services, and when people shouldn't meet in large groups or even leave their homes - that is what it means to attend church.

Several forces work simultaneously which can influence religiosity. First, many people have more free time and so the opportunity cost of time spent on religious activities has decreased. This is especially true for people who have seen disruption in their work due to a decline in economic activity. If things are equal, we hope this leads to increased church attendance. But everything else is not the same now. As the uncertainty of the coronavirus pandemic continues to grow, people with religious backgrounds are likely to turn to their beliefs to find comfort and solace in this time of trouble. However, in recent years, regular church attendance as a percentage of the population has continued to decline in the United States (with declines more pronounced in many European countries). The percentage of the population claiming to have no religion continues to increase. This decline in societal religiosity means that fewer people today than in the past are likely to turn to religious institutions for consolation during this pandemic.

Additionally, the pandemic is causing the social element of church participation to decrease significantly. If a service is being live-streamed, congregants are likely not going to see anyone but their clergy on a screen on Sunday mornings. If a church has no streaming service or if many congregants are not online (due to factors such as age or income), then social distancing may rapidly translate into a rapid reduction in the social benefit of being involved in church. If this pandemic lasts more than a few weeks, some very critical social capital might be lost which may impact churches long-term after they attempt to re-gather once the social restrictions from the pandemic lessen. 
Utilizing services like Zoom or Skype to conduct interactive Sunday school or Bible studies may help to mitigate these effects, but having less opportunity for spontaneous, in-person social interaction may weaken social bonds within churches the longer the pandemic lasts. The more successful churches are at offering ways for people to continue to interact in real-time with one another during the pandemic, the less social capital they should expect to lose. The less successful churches are at providing a genuine sense of community, connectedness, and support during this crisis, the more they will find themselves competing with other streaming media for the attention of believers.

Depending on how many churches react during the crisis may shape public perception of religion. Both internationally and domestically in the United States, there have been several examples of religious services turning into "super-spreading events" that have occurred. A religious group in South Korea (Shincheonji Church of Jesus) in Daegu originally tried to defy their government and resisted sharing attendance records which slowed government response to a COVID-19 outbreak in their country. Choir practice in Washington state turned deadly as 45 out of 60 people present at the practice are now confirmed to have COVID-19 - with 3 hospitalized and 2 who have already died. A pastor in Florida was recently arrested for continuing to hold services at his megachurch in defiance of public health warnings. Liberty University in Lynchburg, Virginia, an Evangelical school, stood out as a notable exception when they were the only major university in Virginia to have students return to campus after spring break in late March - well after other universities closed their doors and moved classes online. If stories like this become a pervasive narrative, this may negatively impact society's view of churches once the pandemic is over. In contrast, there are also many stories of churches being among the first in communities to practice social distancing - long before governments have moved to enforce various forms of social distancing. Many churches have also been very active in making sure members are well taken care of and find physical, mental, and spiritual support for their members during this time of isolation. If these examples become more prominent than the negative stories above, this may have a strong positive effect on the public's perception of Christianity and desire to strengthen their connection with local churches in lockdowns.

Christianity has a long history of believers risking their lives during pandemics to minister to the needs of others. There are many areas today that Christian organizations can also help, but much of the aid given by Christians in the past is now provided by the government. In the current pandemic, healthcare workers are now the ones who are seen risking their own lives for others. These "crowding out" effects may reduce the need for individuals to rely on the ministry of churches to help them through times of 
crisis and rely more on government and medicine than in times past. And what if the lockdowns due to COVID-19 last for months rather than weeks? Will churches begin to hold two services - one in person for those who are confirmed to be immune and another online service for those who are still vulnerable? What will that do for the long-term viability of many churches? What if vulnerable populations are told to still shelter at home after society slowly re-emerges from social distancing? Older individuals are more likely to be active in church, but also are more likely to be vulnerable to the coronavirus. If this scenario plays out, their absence in churches may negatively impact both the social fabric and financial viability of many congregations.

Megachurches with large buildings, which require large budgets funded by an assumption of high attendance, may be particularly impacted. So too might smaller churches in rural regions or poorer urban areas, with congregations whose livelihood may be more impacted by the economic slowdown. Rural churches would also be less likely to have congregants who have active internet users with broadband connections at home. Less connectivity may also be an issue for many Mainline denominations who have congregations that are older than the general population. Putting all of this together means that COVID-19 may have an overall negative effect on societal religiosity. Many congregations are likely to face severe challenges ahead as they attempt to deal with and later recover from the coronavirus. Life may be very different after people begin to slowly come out of lockdown. The uncertainty of the duration and magnitude of the effects of the coronavirus has already caused a severe change in social and economic behavior in countries around the world.

Churches that successfully adapt to these new realities will be most likely to sustain active participation from their congregations during the pandemic and beyond. If physical distancing lasts for a long time, we may see significant religious contraction as well as economic contraction around the world.

In Great Britain, Christian denominations including the Anglican, Catholic, Methodist, Baptist, Reformed, and Presbyterian Churches publish guidelines on adjusting worship concerning the pandemic. In July 2020, North Point Ministries stated that before the pandemic; it normally hosted 30,000 churchgoers every Sunday at seven locations in the Atlanta, Georgia area saying it would only offer services digitally for the rest of the year. The church planter said that contact tracing for exposure to the coronavirus was impossible given the size of the church. On November 30, 2020, one of the pastors at the large California Water of Life church died from COVID-19. He recently took charge of outdoor services after the governor banned indoor services. 
According to a Gallup report by Frank Newport, "the most dramatic result (in religion) has been the very rapid shift of religious services from face-to-face worship to online worship." Even though we know that for nearly one hundred years, the church has used a variety of communication methods to reach its listeners, such as radio, television, and online media.

Gallup said that the cessation of direct worship "was one of the most significant sudden interruptions in religious practice in history. At the Vatican, Pope Francis chose not to convey the traditional blessings every Sunday from the window terrace overlooking St. Peter's Square but rather delivered Sunday's blessings live on the internet, to reduce crowds at the Vatican, as millions of people in northern Italy are affected by the virus and they are undergoing quarantine (BBC News 2020).

In Indonesia, with the existence of Covid-19, all public places are closed, such as places of worship, such as churches, because of this pandemic Christians miss worship in their every life because worshiping through social media is not the same as when we come to a church, and immediately fellowship with God individually, therefore, the presence of Covid-19 reduces the enthusiasm of Christians to come to worship God and be satisfied with Covid-19, so they often forget to worship God.

As written in 1 Timothy 3:16 "and truly great is the secret of our worship, he who has revealed himself in human form is justified in the spirit that appears before the angels, is preached to the Gentile nations who are trusted in the world to be exalted in glory".

which means that the purpose of worshiping God is a useful thing in all respects because it is a spiritual refreshment because in our lives as Christians we are often faced with various kinds of problems, especially the Covid-19 problem, according to 1 pet 2: 9 stated that "of course we as Limited humans have a lot of struggles in living our lives in the world in dealing with these diseases, therefore we need support and comfort through worship because worship is the answer to everything we experience in our lives as people who believe in God because it is through Our Lord's words are reminded again of how we think about a wonderful and wonderful God ".

Romans 12: 1 states that "Therefore, brothers and sisters, with the mercy of God, I advise you that you should present your body as a holy and pleasing offering of life to God, it is your true worship. Because the purpose for humans to come to God's home is to praise and worship God ". From this statement we know that the true essence of the celebration of mass is when the people are present in the house of God and all the words of God are heard directly, which God has prepared six days for His people to work and leaves one day, namely the seventh day to spare. time and worship Him in the house of God.

In the Covid-19 pandemic, worship activities were eliminated and carried out virtually (online), this caused worship activities to be not optimal 
and even led to a lack of community participation in attending church celebrations, such as worship. Many Christians who use social media but do not use social media to seek God's word or attend online worship, instead use social media as a tool to entertain themselves and carry out their work. In Covid19, which should be a collective struggle in the life of every Christian. The church enlivens the concept of true worship in a frame of mind and builds care for our neighbors as Christians who believe in God. Worship at home during the Covid19 pandemic is an attempt by the church to participate and realize God's kingdom on earth.

Reporting from VOA, in the United States, during the lockdown period, not only offices, restaurants, and shops were closed, but also places of worship, especially churches. Christian Indonesians follow this rule by worshiping without having to go to church. The churches were deserted, even deserted on Sundays, a day of worship for Christians. Especially during big celebrations like Christmas and Easter. But this year is quite different; places of worship across the US are adjusting to the harsh reality of the covid-19 pandemic. Some churches remain open to congregants with strict restrictions, while many others have closed. For the Catholic Church, confession before Christmas and Easter is very important. Said a member of the Kasih Anugerah church council, Harry Napitupulu. "It will still be held, only through online. So from the church, the council will still attend because it is determined that only 10 people can attend. So we have 5 assemblies and one pastor, so six, through Facebook we can go live so it will be opened later and all the congregations can listen to it, "he said.

\section{Methodology}

In this research, the writer will use the descriptive qualitative method. The writer uses the descriptive qualitative method because the writer wants to describe the data by referring to the presence of linguistic elements and without calculating it statistically. The descriptive qualitative method will be used to describe the data of this paper. According to Arikunto (2002:22), a descriptive study is a kind of non-hypothesis research and does not need to formulate the hypothesis in steps of the research. Qualitative data is useful for describing words or sentences based on categories to get conclusions. The data is summed, compared with the expected results and the percentage is obtained. Therefore, the qualitative descriptive research stage does not require a hypothesis formula. So, with that, the writer does not need a hypothesis but rather uses an explanation in this analysis.

The Instrument used in this paper was a web-based questionnaire as the research instrument to collect respondents' answers. This kind of research instrument is defined as the most appropriate method to collect the data needed, especially at the time of pandemic to ensure social distancing as one of the health protocols which has been instructed by the government and also to maintain the health all of mankind. The instrument will be distributed 
through online media, especially Google Forms. That is because when the COVID-19 outbreak occurred, all activities stopped applying face-to-face meetings. It was caused by the policy of social distancing in Indonesia. This online survey technique using questionnaire will be used to collect the data about COVID 19 causes a religious recession to KBG Matersalfatores in Catedral Ruteng. The questionnaire that will be used in this study is adapted from Hassan \& Mirza (2020) which will be designed into an URL Link using Google Forms.

The type of questionnaire that will be used in this research is the combination of open-ended and close-ended questions which have been modified by the writer based on their needs. The questionnaire is modified using the Indonesian language because it aims to help the respondents to understand and answer or even fill those questions easily. For the items which deal with open-ended questions, the respondents are free to answer the questions using their own words. While, for the items which deal with closeended questions, the respondents have a limited space to answer the questions because the answers have been set by the writer in form of multiple answers or yes-no answers, so they only have the opportunity to choose one of the appropriate answers.

This type of questionnaire using the Likert scale which is divided into four scale categories, they are: 1) Strongly Agree, 2) Agree 3) Disagree, 4) Strongly Disagree. The questionnaire consists of 20 questions which 7 closeended questions and 13 open-ended questions. The questions that deal with the close-ended item will be answered by using the Likert scale and multiple answers/yes or no answers, while the questions that deal with open-ended items will be answered by using the participant's own words. In collecting the data, the writer will distribute the questionnaire in form of Google form which is the link of the questionnaire to the respondent as participants to achieve authentic data about their perception due to the use of online worship during the Covid-19 pandemic era.

The writer will translate the questionnaire into Indonesia to help the participants to understand and fill the questionnaire appropriately and easily. Next, the writer will collect the participant's answers as the data about their perception of online worship during this pandemic of covid-19. The participants in this paper were residents in Katedral Ruteng, especially in Kampung Maumere. To limit the data, the writer just chooses 26 participants randomly from KBG matersalvatores.

Data analysis activities consist of data reduction, display data, and conclusion drawing/verification data which are carried out interactively and continuously until completion so that the data reaches saturation. 


\section{RESULT AND DISCUSSION}

\subsection{Result}

In this section the researcher will explain the findings and discussion the participant data consisting of 26 randomly selected participants with the following classification 25 participants or parishioners from the KBG Matersalvatores in Kampung Maumere village, cathedral Ruteng and a parish priest from cathedral Ruteng The method is done by distributing web questionnaires and interviews. Researchers make 20 questions with each google form consisting of 10 questions. To limit the data, the researcher only focuses on 12 main questions, either for priests or for people in the Matersalvatores KBG. found as follows:

\section{PARISHIONERS KBG MATERSALVATORES}

1. Identity of the resident (Occupation and age)

The residents in this research chooses randomly,those from KBG Matersalvatores:

\section{A. Occupation}

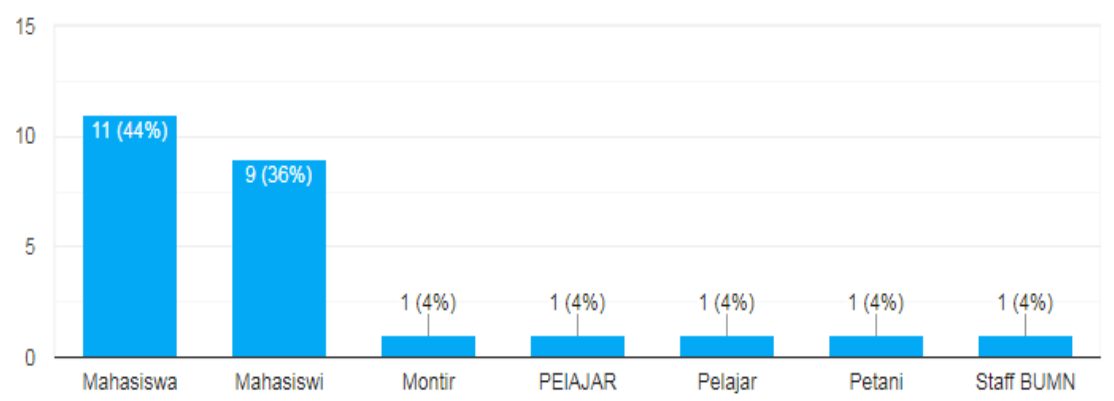

B. Age

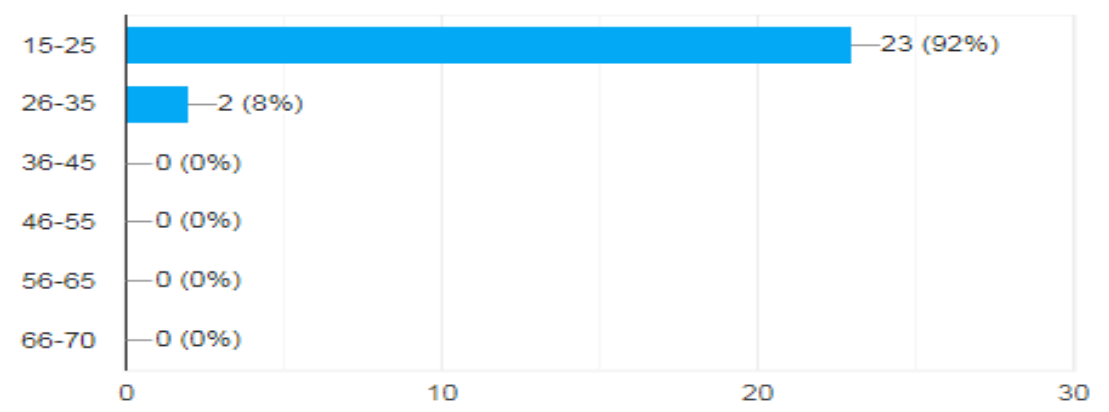

2. Question

a. Has COVID-19 affected worship or spiritual celebrations in your church or parish? 


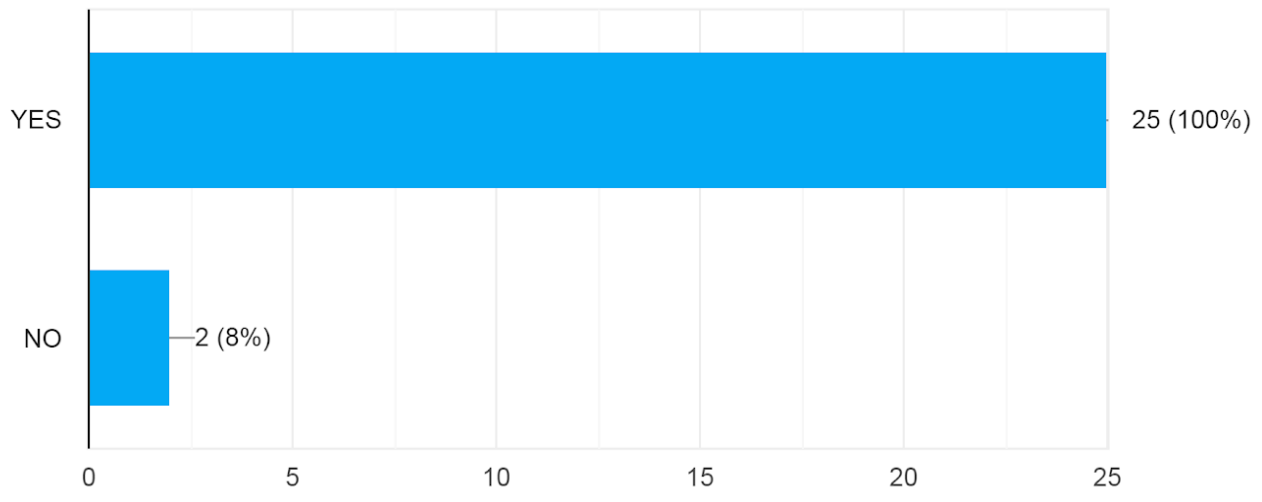

Based on the table above,we can see that 25 participants with the percentage $100 \%$ stated yes if covid-19 affected worship or spiritual celebrations in their church or parish.From the 25 participants, 2 participants in Netral position,who stated yes and No in the same time.

a. What impact has COVID-19 caused in your parish?

\begin{tabular}{|c|c|l|}
\hline NO & PARTICIPANTS & \multicolumn{1}{c|}{ COMMENTS / RESPOND } \\
\hline 1 & COLLEGE STUDENTS & Change from conventional mass to online mass \\
\hline 2 & COLLEGE STUDENTS & $\begin{array}{l}\text { People who want to attend mass celebrations must } \\
\text { be limited, always wearing masks. }\end{array}$ \\
\hline 3 & COLLEGE STUDENTS & $\begin{array}{l}\text { The spiritual activities that are usually carried out } \\
\text { by the church are all done from home. }\end{array}$ \\
\hline 4 & COLLEGE STUDENTS & $\begin{array}{l}\text { The freedom of the people to go to church or } \\
\text { spiritual activities is limited because the number of } \\
\text { people who participate in spiritual celebrations is } \\
\text { limited. }\end{array}$ \\
\hline 5 & COLLEGE STUDENTS & No spiritual celebrations were held \\
\hline 6 & COLLEGE STUDENTS & Mass and other services are held online. \\
\hline 7 & COLLEGE STUDENTS & $\begin{array}{l}\text { When we go to church we still wear masks, and } \\
\text { the people involved in worship are very limited, } \\
\text { etc. }\end{array}$ \\
\hline 8 & FARMER & $\begin{array}{l}\text { Mass celebrations take place online and attendees } \\
\text { are limited in number. }\end{array}$ \\
\hline 9 & STUDENTS & $\begin{array}{l}\text { Mass was held online and some church services } \\
\text { were suspended }\end{array}$ \\
\hline 10 & MECHANIC & Mass is done online \\
\hline 11 & COLLEGE STUDENTS & $\begin{array}{l}\text { So far none, because all parishioners adhere to } \\
\text { good health protocols. }\end{array}$ \\
\hline
\end{tabular}




\begin{tabular}{|c|c|c|}
\hline 12 & COLLEGE STUDENTS & $\begin{array}{l}\text { Limitation on the number of congregants attending } \\
\text { iffline services at church. Because of this, people } \\
\text { have to take part in online worship from home so } \\
\text { that worship is less fun. }\end{array}$ \\
\hline 13 & COLLEGE STUDENTS & $\begin{array}{l}\text { The celebration of the Eucharist was performed } \\
\text { unusually }\end{array}$ \\
\hline 14 & COLLEGE STUDENTS & $\begin{array}{l}\text { The church was closed due to Covid-19. All } \\
\text { parishioners are expected not to celebrate Mass at } \\
\text { church. }\end{array}$ \\
\hline 15 & COLLEGE STUDENTS & There are very few churchgoers \\
\hline 16 & COLLEGE STUDENTS & $\begin{array}{l}\text { Several times livestream mass celebrations, now } \\
\text { restrictions on the number of people }\end{array}$ \\
\hline 17 & COLLEGE STUDENTS & Limitation on the number of people \\
\hline 18 & STUDENTS & $\begin{array}{l}\text { As for impact I think, there is no real activity in the } \\
\text { church }\end{array}$ \\
\hline 19 & COLLEGE STUDENTS & $\begin{array}{l}\text { There have been fewer people / people visiting the } \\
\text { church, receiving charity for the church is no } \\
\text { longer efficient, the lack of church preaching } \\
\text { carried out by priests due to Covid } 19 \text {. The clamor } \\
\text { of the church atmosphere is no longer the same. }\end{array}$ \\
\hline 20 & COLLEGE STUDENTS & $\begin{array}{l}\text { sometimes only a few people come for the } \\
\text { Eucharist. }\end{array}$ \\
\hline 21 & COLLEGE STUDENTS & $\begin{array}{l}\text { There is no Eucharist (Mass) on Sundays or other } \\
\text { holidays. Even if there is, people who can enter the } \\
\text { church are limited. }\end{array}$ \\
\hline 22 & Staff BUMN & $\begin{array}{l}\text { During the covid-19 news Worship is never } \\
\text { celebrated. }\end{array}$ \\
\hline 23 & COLLEGE STUDENTS & $\begin{array}{l}\text { Going to church must follow the schedule set by } \\
\text { the church council. }\end{array}$ \\
\hline 24 & COLLEGE STUDENTS & $\begin{array}{l}\text { Cannot participate in spiritual activities in the } \\
\text { Church }\end{array}$ \\
\hline 25 & COLLEGE STUDENTS & There is no worship until now. \\
\hline
\end{tabular}

Based on the data above, it can conclude that they have differences answered, 14 Participants stated that their conventional worship activities change into online worship,than 11 participants stated that they still allowed to attend the conventional worhsip but limited by the church.

b. Do you agree and feel comfortable having worship services or mass celebrations online compared to conventional mass celebrations (face-to-face) in your parish church? 


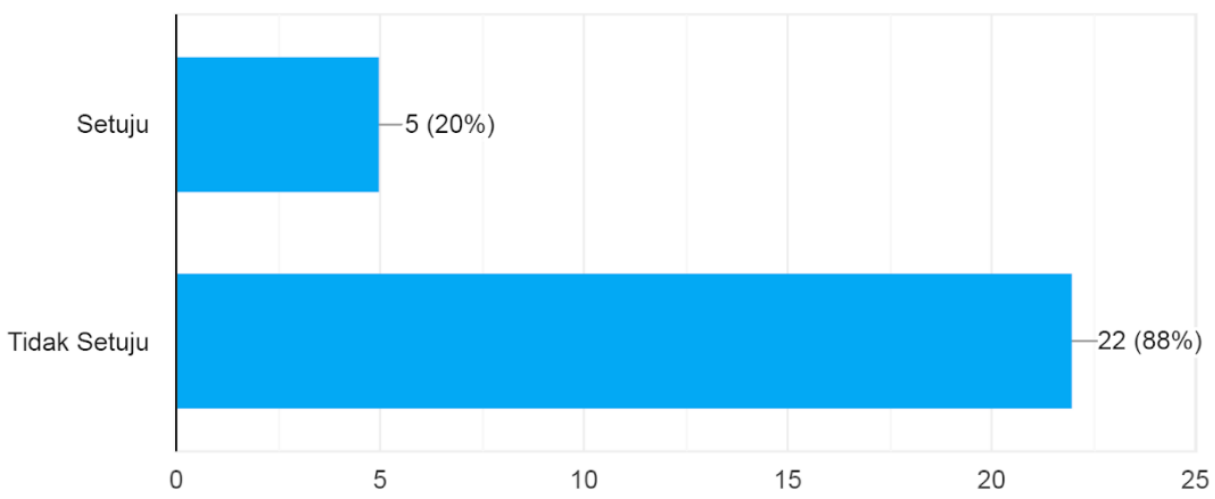

From the table above we can see that, 22 participants with the percentage $88 \%$ disagree if their Online worship more comfort than conventional worship (face-to face in church) while the 5 participants agree if online mass more comfort than conventional worship with the percentage of $20 \%$.

c. Do you agree that online mass celebrations are costly?

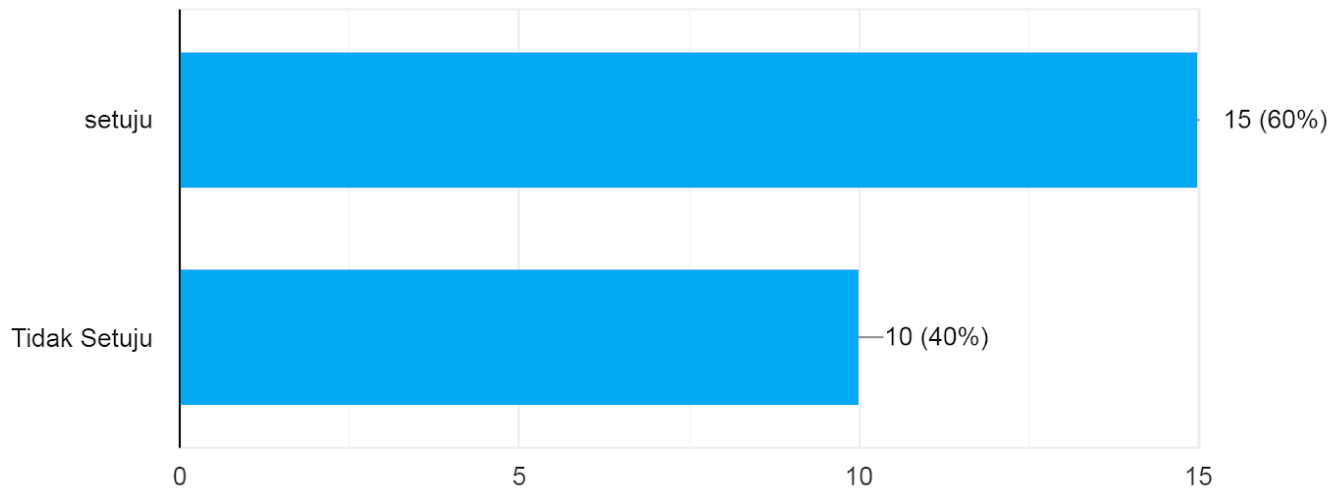

Based on table above, we can see that $60 \%$ with total $15 \%$ participants agree if online worship most costly,while $40 \%$ with total 10 participants disagrre if online worship spend more price.

d. When you don't have a cellphone, laptop, quota, how do you get to participate in online celebrations?

\begin{tabular}{|c|c|l|}
\hline NO & PARTICIPANTS & \multicolumn{1}{c|}{ COMMENTS / RESPOND } \\
\hline 1 & COLLEGE STUDENTS & Don't follow it \\
\hline 2 & COLLEGE STUDENTS & Using radio. \\
\hline 3 & COLLEGE STUDENTS & Follow personally \\
\hline
\end{tabular}




\begin{tabular}{|c|c|c|}
\hline 4 & COLLEGE STUDENTS & $\begin{array}{l}\text { Because there are no tools such as } \\
\text { cellphones, laptops and quotas, I cannot } \\
\text { participate in online celebrations but pray } \\
\text { privately at home }\end{array}$ \\
\hline 5 & COLLEGE STUDENTS & Join those who have HP and Quota \\
\hline 6 & COLLEGE STUDENTS & $\begin{array}{l}\text { Join those who have a laptop, cellphone } \\
\text { and quota. }\end{array}$ \\
\hline 7 & COLLEGE STUDENTS & the way I followed tv broadcast \\
\hline 8 & FARMER & Hear and attend Mass on the radio. \\
\hline 9 & STUDENTS & $\begin{array}{l}\text { Attending mass with a friend who has a } \\
\text { cellphone }\end{array}$ \\
\hline 10 & MECHANIC & $\begin{array}{l}\text { Without having to take part in online } \\
\text { celebrations, if a person is truly "faithful, } \\
\text { he will pray in his own way, despite all the } \\
\text { limited facilities he has. }\end{array}$ \\
\hline 11 & COLLEGE STUDENTS & $\begin{array}{l}\text { Carry out short home worship with the } \\
\text { family. }\end{array}$ \\
\hline 12 & COLLEGE STUDENTS & $\begin{array}{l}\text { Looking for friends or neighbors who have } \\
\text { these facilities so that they can keep up } \\
\text { with the celebration well. }\end{array}$ \\
\hline 13 & COLLEGE STUDENTS & $\begin{array}{l}\text { I think it's enough to prepare a statue or } \\
\text { cross in the room and pray privately. }\end{array}$ \\
\hline 14 & COLLEGE STUDENTS & $\begin{array}{l}\text { Borrow someone else's cellphone then ask } \\
\text { for a hotspot }\end{array}$ \\
\hline 15 & COLLEGE STUDENTS & Join friends who have the means \\
\hline 16 & COLLEGE STUDENTS & Obviously not \\
\hline 17 & COLLEGE STUDENTS & $\begin{array}{l}\text { One way is to build communication with } \\
\text { family, and do joint activities at home such } \\
\text { as sports, worship together }\end{array}$ \\
\hline 18 & STUDENTS & $\begin{array}{l}\text { Take part in an online celebration with a } \\
\text { brother who owns Kouta. }\end{array}$ \\
\hline 19 & COLLEGE STUDENTS & join friends who have \\
\hline 20 & COLLEGE STUDENTS & $\begin{array}{l}\text { Enter the room, close the door, light a } \\
\text { candle, close your eyes and pray. }\end{array}$ \\
\hline 21 & COLLEGE STUDENTS & $\begin{array}{l}\text { Choose to pray privately and read the } \\
\text { scriptures. }\end{array}$ \\
\hline 22 & Staff BUMN & \\
\hline 23 & COLLEGE STUDENTS & $\begin{array}{l}\text { The way I do it is that I take turns } \\
\text { participating in other KBG, namely } \\
\text { Benteng Daud in Perumnas, Mena, which } \\
\text { is carried out by } 4 \text { families and there are } \\
\text { celebrations like Sundays are usually }\end{array}$ \\
\hline
\end{tabular}




\begin{tabular}{|l|l|l|}
\hline & & $\begin{array}{l}\text { carried out in rotation. And these 4 KK are } \\
1 \text { prayer group that has never met directly } \\
\text { with other KBG members and even this 1 } \\
\text { prayer group has become 1 family. }\end{array}$ \\
\hline 24 & COLLEGE STUDENTS & $\begin{array}{l}\text { And as long as Covid has never } \\
\text { participated in an online celebration. So if } \\
\text { you don't have a cellphone, laptop, or even } \\
\text { a koata, it doesn't affect the celebration at } \\
\text { all }\end{array}$ \\
\hline 25 & COLLEGE STUDENTS & Chat with friends or neighbors. \\
\hline
\end{tabular}

From the data above we can conclude that,some of them will tried to get the solution,like join with the other,using radio,or watch through TV broadcast.The others choose to pray privately even with their family or just alone in their room.

e. What do you think if you hear the statement "COVID-19 causes a religious recession (decreased activity of the celebration of the Eucharist, restrictions on people.)

\begin{tabular}{|c|c|l|}
\hline NO & PARTICIPANTS & \multicolumn{1}{c|}{ COMMENTS / RESPOND } \\
\hline 1 & COLLEGE STUDENTS & $\begin{array}{l}\text { I agree, because by itself religion } \\
\text { will erode }\end{array}$ \\
\hline 3 & COLLEGE STUDENTS & $\begin{array}{l}\text { I strongly agree, because during } \\
\text { the pandemic, all activities in the } \\
\text { church were reduced, and many } \\
\text { prayer services were canceled. } \\
\text { very big impact. }\end{array}$ \\
\hline 4 & COLLEGE STUDENTS & $\begin{array}{l}\text { A church is not just a building or a } \\
\text { strong building, but the church is } \\
\text { the unity of the people in } \\
\text { deepening their faith in God. } \\
\text { Therefore, when there was a } \\
\text { statement that the Church was in } \\
\text { decline during the Covid-19 } \\
\text { pandemic, in my opinion it } \\
\text { depends on how each individual } \\
\text { responds or delves into the } \\
\text { situation that is happening. }\end{array}$ \\
\hline 5 & COLLEGE STUDENTS & $\begin{array}{l}\text { The church experienced a setback } \\
\text { during the COVID-19 pandemic, }\end{array}$ \\
\hline
\end{tabular}




\begin{tabular}{|c|c|c|}
\hline & & $\begin{array}{l}\text { because the celebrations during the } \\
\text { pandemic were unusual, for } \\
\text { example the lack of church } \\
\text { services such as the sacrament of } \\
\text { baptism, weddings, etc. }\end{array}$ \\
\hline 6 & COLLEGE STUDENTS & $\begin{array}{l}\text { In my opinion that is not true, } \\
\text { because online mass does not } \\
\text { affect our faith in God. }\end{array}$ \\
\hline 7 & COLLEGE STUDENTS & $\begin{array}{l}\text { My opinion is that the Church has } \\
\text { not experienced a setback, because } \\
\text { the ministry of priests, monks / } \\
\text { nuns remains as before, only the } \\
\text { difference is that it is done online } \\
\text { and sometimes they visit certain } \\
\text { places but are limited by the } \\
\text { attendance. }\end{array}$ \\
\hline 8 & FARMER & $\begin{array}{l}\text { I strongly agree with this } \\
\text { statement, because it is true that } \\
\text { the church experienced many } \\
\text { setbacks during the Covid-19 } \\
\text { Pandemic that is attacking the } \\
\text { world today. }\end{array}$ \\
\hline 9 & STUDENTS & $\begin{array}{l}\text { I really agree with the statement } \\
\text { above, this worldwide covid-19 } \\
\text { has completely eliminated all } \\
\text { activities in the church. }\end{array}$ \\
\hline 10 & MECHANIC & $\begin{array}{l}\text { Yes, I completely agree with the } \\
\text { statement above, the church is } \\
\text { currently experiencing a lot of } \\
\text { setbacks due to covid-19 }\end{array}$ \\
\hline 11 & COLLEGE STUDENTS & $\begin{array}{l}\text { I don't think so. In fact, with the } \\
\text { existence of Covid } 19 \text { the Church } \\
\text { has become more united in prayer. } \\
\text { The church I mean is the people of } \\
\text { Christ himself. }\end{array}$ \\
\hline 12 & COLLEGE STUDENTS & $\begin{array}{l}\text { I don't think so. Just because there } \\
\text { are restrictions on the number of } \\
\text { congregations, and some services } \\
\text { are held online does not } \\
\text { significantly reduce church } \\
\text { attendance in the community. }\end{array}$ \\
\hline 13 & COLLEGE STUDENTS & Maybe \\
\hline
\end{tabular}




\begin{tabular}{|c|c|c|}
\hline 14 & COLLEGE STUDENTS & $\begin{array}{l}\text { Well, that's natural, because during } \\
\text { the pandemic the church was } \\
\text { completely closed, even though it's } \\
\text { now slowly reopening. }\end{array}$ \\
\hline 15 & COLLEGE STUDENTS & No comment \\
\hline 16 & COLLEGE STUDENTS & What setbacks and how? \\
\hline 17 & COLLEGE STUDENTS & Not really \\
\hline 18 & STUDENTS & $\begin{array}{l}\text { In my opinion during the } \\
\text { pandemic, the church has not } \\
\text { experienced any setbacks at all, it's } \\
\text { just that socially there is no } \\
\text { worship, but religiously I think } \\
\text { more and more Catholics are } \\
\text { getting closer to God }\end{array}$ \\
\hline 19 & COLLEGE STUDENTS & $\begin{array}{l}\text { Yes, I agree that the church is } \\
\text { experiencing a setback due to } \\
\text { covid } 19 \text {. }\end{array}$ \\
\hline 20 & College Students & $\begin{array}{l}\text { It is undeniable that at the } \\
\text { beginning of the pandemic, the } \\
\text { church experienced a decline in } \\
\text { various aspects, whether it was } \\
\text { related to activities, income, etc. } \\
\text { However, now everything is back } \\
\text { to normal, although there are some } \\
\text { new habits that must be adhered to. }\end{array}$ \\
\hline 21 & COLLEGE STUDENTS & $\begin{array}{l}\text { In my opinion, if we judge the } \\
\text { decline of the church in terms of } \\
\text { quantity, then I agree that the } \\
\text { church is experiencing decline. } \\
\text { However, it seems to me that the } \\
\text { decline of the church on closer } \\
\text { examination is not certain. Because } \\
\text { the church is a people. People who } \\
\text { believe in Christ, which we call } \\
\text { faith. Faith cannot be measured } \\
\text { solely by how a person prays. In } \\
\text { my opinion, it is not quite accurate } \\
\text { to say that the church experienced } \\
\text { a setback during Covid-19. I rather } \\
\text { see this as a challenge of faith for } \\
\text { every human being who believes in } \\
\text { his Lord. What if the pandemic }\end{array}$ \\
\hline
\end{tabular}




\begin{tabular}{|c|c|c|}
\hline & & $\begin{array}{l}\text { turns out to make people closer to } \\
\text { God through warm personal } \\
\text { meetings through prayer. Again, } \\
\text { this too we cannot measure. }\end{array}$ \\
\hline 22 & COLLEGE STUDENTS & $\begin{array}{l}\text { Yes, that is true, even though the } \\
\text { impact of Covid has made } \\
\text { celebrations abolished, many } \\
\text { people celebrate online, as well as } \\
\text { many people who really long to } \\
\text { attend worship in person. }\end{array}$ \\
\hline 23 & Staff BUMN & $\begin{array}{l}\text { Yes. The reason is that many of the } \\
\text { rites during the celebration of the } \\
\text { Eucharist such as the example of } \\
\text { washing the feet and kissing the } \\
\text { cross at Easter are omitted. }\end{array}$ \\
\hline 24 & COLLEGE STUDENTS & $\begin{array}{l}\text { In my opinion, during covid } 19 \text { the } \\
\text { church did not experience a } \\
\text { setback at all, even though the } \\
\text { community was not allowed to } \\
\text { carry out direct spiritual activities } \\
\text { in the church, but the community } \\
\text { actually got closer to the Church } \\
\text { by carrying out spiritual activities } \\
\text { such as rotating word ceremonies } \\
\text { and other communities also } \\
\text { celebrating online and pray, a in } \\
\text { their respective homes }\end{array}$ \\
\hline 25 & COLLEGE STUDENTS & $\begin{array}{l}\text { Yes, of course, because this makes } \\
\text { the lay people even more distant } \\
\text { from God, maybe even some of } \\
\text { them have forgotten the rituals of } \\
\text { worship and all kinds of prayers } \\
\text { and also spiritual songs }\end{array}$ \\
\hline
\end{tabular}

Based on the data above, it can conclude that,11 participants agree if church was decline during covid-19 in context of Church income decreased because many celebrations were canceled, such as the sacrament of baptism, weddings, and other major celebrations.

The church also does not celebrate the Eucharist on Sundays and other major celebrations, such as at Christmas, Easter, and other major celebrations. While 6 participants diasgree with that statement because they thought that online worship is substitute of conventional worship and it didn't 
make the decline in religious life especially in Church services in all aspect.8 participant in netral position,they said that church in decline during covid-19 but it was not the real recession, that the surface condition, it doesn't mean the faithful in god was lost because of covid-19 and people can attand the conventional worship.

THE PRIEST IN PAROKI ST. MARIA ASSUMPTA CATEDRAL RUTENG

\begin{tabular}{|c|c|c|}
\hline No & Question & Answer \\
\hline 1. & $\begin{array}{l}\text { What do you know about } \\
\text { Covid-19? }\end{array}$ & $\begin{array}{l}\text { Covid is a dangerous disease for human life; } \\
\text { therefore we are required to always obey health } \\
\text { protocols to help prevent the spread of Covid-19. } \\
\text { Covid is also a very deadly virus for human life, } \\
\text { economy and social relations. Therefore we are } \\
\text { asked to maintain a healthy lifestyle so that the } \\
\text { spread of Covid-19 can be prevented by obeying the } \\
\text { health protocol made by the government and also } \\
\text { not forgetting to pray, ask for help from God. }\end{array}$ \\
\hline 2. & $\begin{array}{l}\text { What are the impact of } \\
\text { covid on the church? }\end{array}$ & $\begin{array}{l}\text { The scarcity of mass celebrations } \\
\text { means that the celebration of the } \\
\text { Eucharist is rarely found either in } \\
\text { churches or in BECs. Before the } \\
\text { Covid pandemic hit, mass } \\
\text { celebrations were always made on } \\
\text { Saturdays and Sundays, as well as } \\
\text { wedding celebrations, now mass } \\
\text { celebrations on Saturdays and } \\
\text { Sundays have been reduced, this is } \\
\text { done to reduce and minimize the } \\
\text { spread of the virus. } \\
\text { In the past, the money for charity or } \\
\text { collection reached 12-15 million and } \\
\text { now the collection has decreased to } \\
\text { only 3-5 million. People remember } \\
\text { God more and more. With the } \\
\text { challenges that exist, challenge } \\
\text { people to dare to get closer to God. } \\
\text { People are aware that not only God } \\
\text { exists but we are human, we do not } \\
\text { depend on God but we ourselves also } \\
\text { strive for God to help, in other words } \\
\text { now humans prefer to start all }\end{array}$ \\
\hline
\end{tabular}




\begin{tabular}{|c|c|c|}
\hline & & activities with prayer. \\
\hline 3. & $\begin{array}{l}\text { What are The next step } \\
\text { taken by the church to } \\
\text { prevent the spread of } \\
\text { covid-19? }\end{array}$ & $\begin{array}{l}\text { - Inviting people to adhere to health } \\
\text { protocols, every week the Church } \\
\text { invites people to always pray and } \\
\text { obey health protocols. } \\
\text { Regulate a healthy lifestyle, because } \\
\text { when the body has subordinate } \\
\text { diseases, the virus will become more } \\
\text { widespread and cause death. } \\
\text { Avoiding crowds of the masses, } \\
\text { when there is a mass service at a } \\
\text { church, parish area, or BEC., The } \\
\text { parish priest always encourages } \\
\text { people to minimize the crowd by } \\
\text { limiting the attendees and sitting at a } \\
\text { distance. }\end{array}$ \\
\hline 4. & $\begin{array}{l}\text { Has the presence of a } \\
\text { pandemic affected mass } \\
\text { celebrations. }\end{array}$ & $\begin{array}{l}\text { Several months ago, when the death curve was high } \\
\text { due to the Covid pandemic, mass celebrations were } \\
\text { abolished, churches were closed and people were } \\
\text { invited to hold mass online from their homes, all } \\
\text { wedding celebrations, baths were abolished to } \\
\text { prevent the spread of the Covid-19 virus. When the } \\
\text { covid-19 virus curve decreased, the Eucharistic } \\
\text { celebration resumed, group mass celebrations were } \\
\text { held again, but communion celebrations were } \\
\text { abolished, church attendance was limited to prevent } \\
\text { the formation of new clusters. }\end{array}$ \\
\hline 5. & $\begin{array}{l}\text { Does the priest feel } \\
\text { comfortable when } \\
\text { performing mass online? }\end{array}$ & $\begin{array}{l}\text { I am not comfortable when carrying out mass } \\
\text { online, just because of the demands of Covid-19 } \\
\text { and the people who thirst for God so we are taking } \\
\text { this step even though this is a very difficult and } \\
\text { worst decision, in the sense that there is no other } \\
\text { choice to replace the celebration Eucharist. }\end{array}$ \\
\hline 6. & $\begin{array}{l}\text { Does the priest agree } \\
\text { when hearing the } \\
\text { statement that online } \\
\text { Mass costs a lot of } \\
\text { money? }\end{array}$ & $\begin{array}{l}\text { Yes, it is very costly, because when we carry out } \\
\text { online mass we will need benefits such as } \\
\text { electricity, adequate electronic equipment, and costs } \\
\text { to pay or buy the quota. }\end{array}$ \\
\hline 7. & $\begin{array}{l}\text { What was the opinion of } \\
\text { the priest himself when } \\
\text { he heard the statement } \\
\text { "The Church is in }\end{array}$ & $\begin{array}{l}\text { This is not entirely true, in the sense that the } \\
\text { recession the church refers to is a setback because } \\
\text { people who do not attend church do not pray. In } \\
\text { terms of material, the church has experienced a }\end{array}$ \\
\hline
\end{tabular}




\begin{tabular}{|l|l|}
\hline Recession" & $\begin{array}{l}\text { setback; it is because during the crisis the church } \\
\text { experienced a shortage in the amount of collection } \\
\text { money, charity money, this caused a very serious } \\
\text { crisis for the church, because the church could live } \\
\text { from the giving of the people, such as charity, } \\
\text { collection. From a spiritual perspective the church } \\
\text { has experienced a setback due to the Covid } \\
\text { pandemic attacking all sectors of community life, be } \\
\text { it the economic, social, political, cultural, and other } \\
\text { sectors, this has caused the community to focus on } \\
\text { work and earn a fortune which causes church } \\
\text { members not to attend online mass. , as well as } \\
\text { others who do not have cell phones or supporting } \\
\text { devices to attend online mass celebrations. }\end{array}$ \\
\hline
\end{tabular}

Based of the data above we can conclude that father benediktus bensi,pr church have recession because there are some factors explain that priest work hard in preaching the gospel because they cannot meet directly with the people and the collections and donations that are decreasing, given the essence of this eucharistic celebration when many people are present in the house of God.

\subsection{Discussion}

The residents in KBG Matersalvatores agree if their parish was affect by covid-19, and the effect was there is no conventional worship.It was replaced with online worship.The other effect was some residents allow to attend the conventional worship but the people who take a part in there restricted by the church. They also stated that online worship spend more cost than conventional worship. In order to still be able to attend online worship ,people do several things, such as join with the friend who have the complete facilities,like hp,laptop an quota,or using radio and watched through television broadcast. The other used private manner like, do private prayer in their room or with their family,so that they will not be left behind in the celebration of mass.In Last question some of them agree if covid-19 causes religious recession in some context like, there were no conventional worship in any aspect,such as,Sunday mass, weding worship,or in the important worship in christianity. The others disagree with that statement because they can followed the worship through online mass. The others in the netral position, like, they agree if covid-19 causes the decline of the church but they also disagree of covid-19 the will decrease people faithful for God.

According to Mr. Benediktus Bensi,Pr as a priest at cathedral ruteng, answer the first question about covid-19, he said Covid is a dangerous disease for human life; therefore, as priests they are required to always comply with health protocols to help 
prevent the spread of Covid-19. As a priest, he is required to disseminate instructions to fight covid-19 through sermons at online mass celebrations or conveying this information to KBG group leaders. He also said that the impact of covid-19 has also been felt by the Church, such as the scarcity of Eucharistic celebrations making Eucharistic celebrations rarely found both in churches and at KBG. Before the Corona virus spread, ecristy celebrations were always held on Saturdays and Sundays, as well as wedding celebrations. Now the Eucharistic celebration on Saturdays and Sundays as well as wedding ceremonies are reduced or almost nonexistent. The reason is, the local government issued a regulation that limits mass visitors to reduce and overcome the transmission of Covid-19, so, mass visitors decreased which led to a decrease in the number of collections and donations.

In the past, the money for charity or collection reached 12-15 million and now the collection has decreased to only 3-5 million. People remember God more and more. With the challenges that exist, challenge people to dare to get closer to God. People are aware that not only God exists but we are human too. We do not depend on God, but we also strive for God to help. In other words, now humans prefer to start all activities with prayer.

According to his confession on Wednesday 26 May 2021 He is uncomfortable when holding mass online, only because of the demands of Covid-19 and people who are thirsty for God, they was taking this step even though this is a very difficult and worst decision, in the sense that there is no other choice to replace the Eucharistic celebration. He said dealing with religious recession, for church recession is people who do not attend church and do not pray. According to recession materially, the church experienced decline; because, during the crisis, the church experienced a shortage of charity. This has created a very serious crisis for the church, because the church can make a living from the gifts of the people, such as alms, collections. Spiritually, the church has experienced a setback due to the Covid outbreak which has hit all sectors of community life, be it the economic, social, political, cultural and other sectors. This caused the community to focus on working and looking for a fortune which resulted in church members not attending online mass. 


\section{REFERENCES}

Dein,Simon, and friends.2020__COVID-19, mental health and religion: an agenda for future research. Cited from:https://www.researchgate.net/publication/341935126_COVID 19_mental_health_and_religion_an_agenda_for_future_research

Sulkowski,Lukasz. 2020. Impact of COVID-19 Pandemic on Organization of Religious Behaviour in Different Christian Denominations in Poland Cited from https://www.researchgate.net/publication/341519155_Impact_of_COVID 19_Pandemic_on_Organization_of_Religious_Behaviour_in_Different_Christian_De nominations_in_Poland.

Holland,bryan.2020. Will Covid-19 Cause A Religious Recession?. Cited from https://religionanddiplomacy.org/2020/04/08/will-covid-19-cause-a-religious$\underline{\text { recession/ }}$

Ruswandi,Andi.2020._Religious community responses to COVID-19: Case study on Muslim small community.cited from http://digilib.uinsgd.ac.id/31190/

MClaren,peter.2020.cited

from.https://digitalcommons.chapman.edu/education_articles/258/

Wildman,wesley.j and friends.2020. Religion and the covid-19 pandemic. Cited from https://www.tandfonline.com/doi/full/10.1080/2153599X.2020.1749339

Kevern,peter, an friends.2020.The Contribution of Church-Based Networks to Social Care in the Coronavirus Pandemic and Beyond: The Case of Pastoral da Pessoa Idosa in Brazil. Cited from https://core.ac.uk/display/334429024

Smother,hanna, and friends.2020.The gendered Religious response to state action on the corona virus pandemic. Cited from

https://www.cambridge.org/core/journals/politics-and-gender/article/genderedreligious-response-to-state-action-on-the-coronavirus pandemic/3C2C1FF26846CD3CB9D287C65184E8C6 